\title{
ВИКЛАДАННЯ ЖУРНАЛІСТИКИ В УКРАЇНІ НА СУЧАСНОМУ ЕТАПІ: ПРОБЛЕМИ ТЕОРІї ТА ПРАКТИКИ
}

\author{
С. В. Жигун
}

\begin{abstract}
Жигун С. В. Викладання журналістики в Україні на сучасному етапі: проблеми теорії та практики. Проблеми викладання журналістики на сучасному етапі видається ефективним об'єднати у три групи: 1) пов'язані із переходом практики від журналістики, зорієнтованої на коментар, до журналістики, зорієнтованої на інформацію (диспропорційний розподіл годин, суперечливість підручників тощо); 2) зумовлені появою нових медіа, формуванням глобальної журналістики та зміною засобів виробництва; 3) спричинені потребою змінити спосіб викладання, перейшовши від менторства до фасилітації.
\end{abstract}

Ключові слова: журналістика коментаря; інформаційна журналістика; нові медіа; глобальна журналістика; фасилітація.

Жигун С. В. Преподавание журналистики в Украине на современном этапе: проблемы теории и практики. Проблемы преподавания журналистики на современном этапе эффективно объединить в три группы: 1) связанные с переходом практики от журналистики, ориентированной на комментарий, к журналистике, ориентированной на информацию (диспропорциональное распределение часов, противоречивость учебников и т.д.); 2) обусловленные появлением новых медиа, формированием глобальной журналистики и сменой средств производства; 3) вызванные необходимостью изменить способ преподавания, перейдя от менторства к фасилитации.

Ключевые слова: журналистика комментария; информационная журналистика; новые медиа; глобальная журналистика; фасилитация.

Zhygun S. $V$. Teaching Journalism in Ukraine at the Present Period: the Problems of Theory and Practice. It seems effectively to unite problems of teaching journalism at the present period in three groups: 1) connected with the practice transition from the journalism focused on the comment to the journalism focused on information (disproportional distribution of hours, discrepancy of textbooks and so forth); 2) caused by emergence of new media, formation of global journalism and change of means of production; 3 ) caused by the need to change a way of teaching, having passed from mentoring to facilitation.

Keywords: comment journalism; information journalism; new media; global journalism; facilitation.

Навколо питання журналістської освіти в Україні вже понад 10 років вирують дискуciï, при цьому ведуться вони переважно не в колі науковців-теоретиків, сторонами їх стають викладачі та практики, переростаючи подекуди у відверті протистояння (випадки демонстративної відмови брати на роботу випускників-журналістів певних вишів; флешмоб \#за_якісну_освіту). Дослідження якості журналістської освіти в Україні, грунтоване на оцінці низки показників кафедр та факультетів журналістики, а також опитуванні працівників медіа сфери та випускників-журналістів виявило такі проблеми: незадовільна якість наповнення курсів, брак практичних навичок; обтяжливий спадок філологічної традиції (добір дисциплін та філософія підготовки в цілому); незадовільний рівень компетентності викладачів; слабке технічне забезпечення; обмеженість контактів навчальних закладів i практиків, слабка інтеграція у міжнародний контекст; слабка комунікація з аудиторією (відсутність сайтів) ${ }^{1}$. Практики закидають сучасній журналістській освіті викладання журналістики як науки (чи творчості), а не як фаху, а конкретніше - брак дисциплін, що відпрацьовували б пошук та перевірку інформації, конструювання матеріалу, виховували б комунікатора, забезпечували б обізнаність в конкретній темі та журналістських стан-

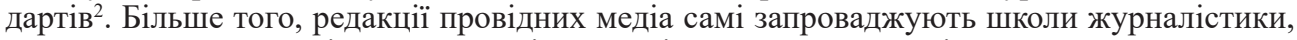
створюючи конкуренцію вишам. У цій ситуації представники освіти виправдовуються потребами відповідати вимогам міністерства і низькою мотивацією студентів ${ }^{3}$. Або ж переходять у наступ, звинувачуючи практиків у незацікавленості освітою (В. Різун ${ }^{4}$ чи непридатності до викладання (I. Михайлин $\left.{ }^{5}\right)$. 
Таким чином актуальність пропонованої статті викликана необхідністю оцінити кореляцію журналістської практики та освіти 3 точки зору ії відповідності сучасним потребам суспільства, зокрема й інтеграції в європейський культурний простір, визначивши причини кризи та можливі шляхи виходу з неї. Матеріалом дослідження стануть вітчизняні та зарубіжні (перекладні) підручники з журналістського фаху, програми навчальних курсів, матеріали дискусій та емпіричний досвід.

Журналістська освіта в Україні нараховує майже сто років. Це не так вже й мало, принаймні цього часу достатньо, щоб сформувати певну традицію. Щоправда, iї зародження й дві третини часу розвитку припали на період перебування України у складі Радянського Союзу, де журналістика була одним з інструментів пропаганди та визначалася особливостями тоталітарної системи. Тому закономірно, що зміна суспільно-політичного ладу потребувала й переінакшення журналістики. Йдеться про зміни правового регулювання діяльності 3МI, уможливлення недержавних форм власності, а також модифікацію коментувальної традиції журналістики, якою бачилося повернення до національних джерел. Ці внутрішні потреби мали реалізовуватися в час, коли в світі поширювалися нові технічні засоби, які суттєво змінювали можливості сучасної журналістики, а також під впливом глобалізації оформлювалися міжнародні стандарти якості та поширювалася журналістика, зорієнтована на факт. Все це зумовлювало необхідність швидких і посутніх змін у журналістській освіті. Втім, видається правомірним визнати, що не всім викликам було приділено належну і вчасну увагу.

Видається правомірним вважати причинами кризи журналістської освіти 1) перехід практики до інформаційної моделі журналістики, у той час як освіта лишилася на позиціях журналістики, зорієнтованої на коментар; 2) появу нових медіа та зміну засобів виробництва; 3) застарілість менторства як педагогічної моделі, яке мусить бути замінене на фасилітацію (що передбачає організацію процесу колективного розв'язання проблем). При цьому варто визнати, що ці причини мають внутрішні зв'язки між собою.

Класична традиція журналістики, зорієнтованої на коментар, надає особливої ролі особі журналіста, що дає оцінку подіям і суспільним тенденціям, відверто обстоюючи певну позицію. Така журналістика сформувалася у країнах, де 3 тих чи інших причин комерціалізація преси була слабкою, ЗМІ використовували для політичної боротьби. Журналісти в цій традиції спонукають читачів до рішучих дій в умовах соціальних дискусій і часто самі очолюють політичні чи суспільні рухи по формі була коментувальною, однак за відсутності політичного паралелізму (тобто усі ЗМІ відбивали погляди єдиної політичної партії) журналіст не мав можливості обирати цінності, які б відстоював. Тому центральним питанням журналістської майстерності було не «що?», а «як?». 3 початком демократизації українська журналістика відмовилась від цензури, однак коментувальна журналістика зберігалася: їі якості чудово надавалися для боротьби за Незалежність і розбудови національної держави. Водночас, у 1990-х роках в український інформаційний простір проникають ідеї інформаційної журналістики, притаманної ліберальній медіа-системі, де завдання журналіста визначають як інформуючи сприяти порозумінню в суспільстві (або ж «інформаційне забезпечення досягнення масового розуміння» ${ }^{7}$. Іноземні професійні організації видають літературу та проводять тренінги, поширюючи ідеї нейтральності журналіста щодо подій, що висвітлюються; збалансованість поглядів та інші стандарти якості. Зважаючи на публікації в «Медіакритиці», «Нарpy.misto.od.ua», «mediasapiens.ua», варто визнати, що журналістика факту сприймається провідними вітчизняними практиками як норма, з позиції якої оцінюється інформаційний простір.

Конфлікт двох традицій відчутно позначається на журналістській освіті. Почнімо 3 того, що вітчизняні підручники в більшості своїй написані в руслі журналістики коментаря. Скажімо, популярні в Україні підручники В. Здоровеги ${ }^{8}$, I. Михайлина ${ }^{9}$, В. Карпенка ${ }^{10}$, які рекомендуються слухачам найрізноманітніших курсів, трактують специфіку журналістського фаху саме 3 цих позицій. У них акцентується увага на особі журналіста, що окрім фахових знань, мусить мати широкі гуманітарні знання та високі моральні якості. Це постать культуртрегера (цивілізатора), поводиря суспільства, який стоїть поруч літератора, а тому спосіб писання у цих підручниках подається з точки зору філологічної традиції. Скажімо, В Здоровега описує творчий процес, користуючись термінами «задум», 
«тема», «концепція», «ідея твору», «композиція», «конфлікт», «сюжет» (Для порівняння I. Аньєс ${ }^{11}$ описує його у поняттях «ключова ідея», «кут зору», «план», «точка входу», «атака», «зачіпки» та інших, підкреслюючи іншу природу журналістського тексту проти літературного). І. Михайлин навіть вписує систему жанрів журналістики у систему літературних. Попри увесь цікавий матеріал, який пропонують ці підручники, вони не відповідають на, як здається, дуже важливе питання, що поставила під час конференції 2005 року Тетяна Райда, шеф-редактор телекомпанії «Харківські новини»: «Навіщо мені журналістська освіта, якщо я маю іншу гуманітарну вищу освіту?» ${ }^{12}$.

У концепції ліберальної медіа-системи журналістика не творчість, а фах, який регулюється законами й стандартами. Потребу ввести журналістські стандарти до переліку дисциплін сформулювали в підсумку міжнародної науково-практичної конференції «Журналістика-2005 у контексті сучасних професійних стандартів та трансформації журналістської освіти», рекомендуючи «розробити план щодо запровадження в навчальний процес вишів, де готують журналістські кадри, сучасних професійних та етичних журналістських стандартів» ${ }^{13}$. За матеріалами огляду О. Піддубної $(2016)^{14}$, 339 навчальних закладів ці стандарти викладають в Інституті журналістики Київського Національного Університету імені Тараса Шевченка, Інституті журналістики Київського Університету імені Бориса Грінченка (в межах комплексного курсу), Київському міжнародному університеті, Відкритому Міжнародному Університеті Розвитку Людини «Україна», Києво-Могилянській Академії, Українському Католицькому Університеті, Бердянському державному педагогічному університеті, Маріупольському державному університеті, Тернопільському національному педагогічному університеті імені В. Гнатюка, Прикарпатському національному університеті імені В. Стефаника, Полтавському національному педагогічному університеті імені В. Г. Короленка (тобто 11 вишах). Втім, як свідчить дослідження О. Кутовенко, ефективність цих курсів випускники оцінюють як недостатню, вказуючи на потребу «більше розповідати про реальні етичні загрози та проблеми, ніж говорити про закордонний досвід чи ідеалізовувати (sic!) те, чого бракує українській журналістиці» ${ }^{15}$.

3 вивченням правових основ функціонування ЗМІ значно гірше - лише сім вишів у згаданому огляді пропонують окремий курс «Медіаправо» чи «Правове забезпечення діяльності ЗМІ». Вітчизняні підручники 1990-х зазвичай не містили такої теми (для порівняння, IREX PROMEDIA в той час випустили кілька брошур «Правничі засади діяльності журналістів в Україні»), далі почали охоплювати ії вибіркові аспекти (наприклад, підручник В. Яковця «Телевізійна журналістика» ${ }^{16}$ має пункт «Міжнародно-правове регулювання громадського мовлення», підручник «Журналістський фах: газетно-журнальне виробництво» Т. Приступенко та ін. ${ }^{17}$ оглядає законодавчі норми під обраним кутом зору: свободи слова), а згодом з'явилися підручники повністю присвячені цій темі (О. Кузнєцової ${ }^{18}$, Т. Приступенко ${ }^{19}$ ). Втім, слід визнати, що попри фахові огляди українських законодавчих норм, автори часом загострюють увагу на правах журналіста та відсувають у бік обов'язки. Скажімо, у першому зі згаданих підручників Т. Приступенко, зазначаючи існування вмотивованих обмежень свободи слова, автор їх не перераховує; згадуючи про інформацію з обмеженим доступом - не роз'яснює; про існування обмежень щодо оприлюднення рекламної інформації не згадує. Й загальний теоретико-науковий виклад не сприяє формуванню практичних знань: таких, як сформулювати інформаційний запит, як отримати (і не втратити) акредитацію, як подавати спростування тощо.

Одним $з$ наслідків такого часткового вивчення правових основ стала безпорадність багатьох журналістів в умовах війни, коли вони розголошували інформацію про особовий склад, чисельність, озброєння армії, наражаючи на небезпеку людей. Але й у мирних темах маємо багато прикладів оприлюднення персональних даних, конфіденційної інформації, неналежного маркування реклами тощо. Тож очевидно, що усвідомлення високої місії мусить бути підкріплене знанням конкретних норм та стандартів.

Іншою проблемою журналістської освіти, зумовленою переходом до журналістики факту, $є$ дисбаланс у розподілі годин. Студентам-журналістам пропонують набір гуманітарних дисциплін, формуючи компетентність культуртрегера. Як свідчить аналіз громадського об'єднання «Детектор медіа», формально в більшості освітніх програм бакалаврату показники наявності дисциплін професійного спрямування становлять від 
$30 \%$ до $45 \%$ годин ${ }^{20}$. Гіршою є ситуація з магістерськими програмами, де такі показники можуть опускатися до $20 \%{ }^{21}$. Втім, автори дослідження коментують ці позитивні дані: «Проте, якщо розглядати запропоновані в планах дисципліни більш детально, картина буде не такою оптимістичною. Також залишається відкритим питання якості викладання цих дисциплін» ${ }^{22}$. Однією $з$ проблем бачиться дисбаланс уваги, котра приділяється жанрам, як сталим формам, у які втілюється повідомлення, і майже не приділяється методам пошуку та перевірки інформації; створенню тексту, але не презентації його; індивідуальній роботі, але не організації роботи редакції. Крім того, варто також говорити про недостатню ефективність супроводу лекцій семінарами, які необхідно доповнювати тренінгами. Як показує практика, можна розібрати найрізноманітніші види інтерв'ю та ознайомити 3 «хорошими» і «поганими» питаннями Дж. Саватськи на лекції; під час практичного опрацювати типи інтерв'юерів, сформулювавши рекомендації роботи 3 ними, але зустріч зі «справжнім» героєм виявляє, що знання теорії не гарантує вміння іiї застосовувати.

Інтриги викладанню додають перекладні підручники («Журналістика» Ш. РусМоля ${ }^{23}$, «Підручник із журналістики» I. Аньєса, «Новинна журналістика» 3. Вайшенберга ${ }^{24}$, «Інтернет-журналістика: робота журналіста і редактора в нових ЗМІ» Р. Крей$\mathrm{ra}^{25}$ ), які займають не надто заповнену нішу та вносять інші, проти українських, оцінки і реалії. Для мотивованих студентів вони - безцінне джерело компенсації недоотриманих знань, однак справляють і певний деструктивний вплив: розхитують українську традицію. Скажімо, в українській журналістиці виділяють три групи жанрів: інформаційні, аналітичні та публіцистично-художні. І. Аньєс описує сім груп, Ш. Рус-Моль поділяє на дві групи + змішані, 3. Вайшенберг говорить про форми зображення (повідомлення, власна думка, розважальна). При цьому звичні українцям жанри опиняються в найрізноманітніших позиціях: скажімо, нарис, що є для нас художньо-публіцистичним жанром, Ш. Рус-Моль розглядає як інформаційний, а I. Аньєс розглядає репортаж серед «Розповідей». Осмислення різних підходів, як і проблема перекладу, є цікавою темою для науковців, однак сприяє появі текстів-кентаврів, заплутує студентів і ускладнює оцінювання їхніх матеріалів.

Другою причиною кризи журналістської освіти варто вважати появу нових медіа та засобів виробництва, що також викликало зміни в критеріях оцінки повідомлення (нові виміри понять «оперативність», «близькість», «важливість» тощо), появу нової тематики (IT, глобальна журналістика) тощо. Це спонукає суттєво оновлювати пропоновані курси та їх наповнення. Окрім он-лайн журналістики, у вишах сьогодні викладають курси інфографіки, пошукової оптимізації, ведення блогів, роботи в соціальних мережах, роботи на мультимедійних платформах та в конвергентних ЗМI (таких, що поєднують різні формати подання інформації). Однак найчастотніший показник інноваційних курсів у програмі - від 3 до 5. Основна складність тут пов'язана із практичною підготовкою викладачів, необхідністю розвиватися й бути практиком, оскільки в сучасних умовах фахівці такого профілю економічно не мотивовані викладати.

Володіння викладачем сучасними технологіями на достатньому рівні суттєво полегшує роботу. Якщо раніше одним з головних нарікань освітян була застарілість чи відсутність матеріально-технічної бази, то нині програмне забезпечення дозволяє навчати верстати, монтувати, обробляти фото на персональних комп'ютерах; новітні технології дають змогу розміщувати відео та аудіо продукт в мережі, отримуючи зворотній зв'язок 3 аудиторією. Крім того, мережа сьогодні містить безліч ресурсів, без знання яких компетентність журналіста не буде достатньою: «Доступ до правди» (https://dostup.pravda.com. ua), реєстр судових рішень (http://www.reyestr.court.gov.ua), кабінет електронних сервісів (https://kap.minjust.gov.ua) тощо, а тому викладачеві необхідно постійно підтримувати власну поінформованість, орієнтуючись не лише на наукову, фахову літературу, але й на новини практиків.

Більшість нинішніх студентів, що виросли в умовах екранної культури, є візуалами і цікавляться сучасними технологіями. Тому викладання у форматі класичних лекцій/семінарів втрачає ефективність. Викладачі мусять використовувати презентації, ментальні карти, хмари тегів, технологічні карти, веб-квести тощо. Також мережа пропонує велику кількість допоміжних ресурсів: від відеокурсів Прометеус, які читають авторитетні ви- 
кладачі, до аматорських роликів на Ютюбі чи блогів. Оскільки студенти добре володіють інформаційними технологіями і програмами, часто мають досвід роботи в мережі, потреба перейти у викладанні від менторства до фасилітації видається очевидною. Фасилітація як організація керованого процесу колективного розв'язання проблем у групі сприятиме запровадженню проектного навчання (власне, системи навчання, за якої студенти набувають знань під час планування та виконання практичних завдань). У попереднє десятиліття проектний метод застосовували для підсумкового контролю: на завершення курсу чи навчання в цілому студенти (одноосібно чи малими групами) виготовляли журналістський продукт. Однак у такому разі роль викладача вичерпується до початку проекту. А. Захарченко (Інститут журналістики Київського національного університету) застосовує проектний метод упродовж читання дисципліни, доповнивши оцінювання проекту оцінюванням виконання проміжних практичних завдань ${ }^{26}$, подібну практику застосовують і О. Ситник та П. Салига (Інститут журналістики Київського національного університету / Київського національного університету культури і мистецтв). У разі технічної неможливості створювати готовий продукт можна підготувати набір виробничих проблем, варіанти розв'язання яких розглядати на парах (так званий кейс-метод). Обидва ці методи (проектного навчання та кейс-метод) $€$ інтерактивні, даючи змогу наблизити навчання до практики та навчаючи застосовувати набуті знання для вирішення конкретних завдань.

Очевидно, названі причини кризи в журналістській освіті не всеохопні, однак спрямований перехід до журналістики факту в змісті та фасилітації в формі викладання знімуть такі нарікання практиків як незнання норм і стандартів, невміння застосовувати знання та діяти в складних умовах. Нові ЗМІ та засоби виробництва потребують більших зусиль від викладачів, які мусять бути підкріплені курсами підвищення кваліфікації.

${ }^{1}$ Стан журналістської освіти на факультетах журналістики в Україні (результати пілотного дослідження). Спеціальний звіт / ГО «Детектор медіа». Київ: Детектор медіа, 2016. С. 6.

2 Для танго потрібні двоє. URL: http://osvita.mediasapiens.ua/mediaprosvita/education/dlya tango potribni_dvoe_chi_e_vzaemodiya_mizh_osvityanami_ta_mediaindustrieyu/ (дата звернення: 09.05.2017).

${ }^{3}$ Там само.

${ }^{4}$ Різун B. У медійної галузі немає запиту на підготовку кадрів. URL: http://osvita.mediasapiens. ua/mediaprosvita/education/volodimir_rizun_u_mediynoi_galuzi_nemae_zapitu_na_pidgotovku_kadriv/ (дата звернення: 09.05.2017).

${ }^{5}$ Михайлин I. Журналістська освіта і наука. Суми, 2009. С. 27-30.

${ }^{6}$ Галлін Д. С., Манчіні П. Сучасні медіасистеми: три моделі відносин ЗМІ та політики / Пер. 3 англ. К.: Наука, 2008. С. 85-87.

${ }^{7}$ Владимиров В. М. Журналістика, особа, суспільство: проблеми розуміння: монографія. К.: Київ. нац. ун-т ім. Тараса Шевченка, 2003. С. 76.

8 Здоровега В. Й. Теорія і методика журналістської творчості: Підручник. 2-ге вид., перероб. і допов. Львів: ПАІС, 2004. 268 с.

${ }_{9}^{9}$ Михайлин I. Основи журналістики. 5-те вид., доповн. і доопр. К.: Центр учбової літератури, 2011. $496 \mathrm{c}$.

10 Карпенко В. Журналістика: основи професіональної комунікації: навчальний посібник для вузів. К.: Нора-прінт, 2002. 348 с.

${ }^{11}$ Аньєс I. Підручник із журналістики. К.: ВД Києво-Могилянська Академія, 2013. 544 с.

${ }^{12}$ Нові моделі навчання журналістів: час від слів переходити до справ. URL: http://ua.telekritika. ua/news/print/3909 (дата звернення: 09.05.2017).

13 Там само.

${ }^{14}$ Піддубна О. Де готують журналістів в Україні? URL: http://osvita.mediasapiens.ua/mediaprosvita/ education/de_gotuyut_zhurnalistiv_v_ukraini/ (дата звернення: 09.05.2017).

${ }^{15}$ Кутовенко О. Журналістська етика в Україні: розбіжності між практикою та теорією. URL: http://ua.ejo-online.eu/725/етика-та-якість/журналістська-етика-в-україні-розбіж (дата звернення: 09.05.2017).

${ }^{16}$ Яковець А. Телевізійна журналістика: теорія і практика. К.: ВД “Києво-Могилянська Академія”, 2007. 239 с.

17 Журналістський фах: газетно-журнальне виробництво: навчальний посібник / Т. О. Приступенко, Р. В. Радчик, М. К. Василенко та ін.; за ред. В. В. Різуна. К.: Видавничо-поліграфічний центр «Київський університет», 2010. 287 с. 
${ }^{18}$ Кузнейова О. Д. Професійна етика журналіста: посібник. Львів: ПАЇС, 2007. 246 с.

${ }^{19}$ Приступенко T. Теорія журналістики: етичні та правові засади діяльності засобів масової інформації. К.: Знання, 2011.351 c.

${ }^{20}$ Стан журналістської освіти ... С. 17.

${ }^{21}$ Там само. С. 18

${ }^{22}$ Там само. C. 20

${ }^{23}$ Рус-Моль Ш. Журналістика: посібник / Пер. з нім. В. Климченко, В. Олійник. К.: Академія українскої преси, 2013. 345 с.

${ }^{24}$ Вайшенберг 3. Новинна журналістика: навчальний посібник / За загал. ред. В. Ф. Іванова. К.: Академія Української преси, 2011. 262 с.

${ }^{25}$ Крейг Р. Інтернет-журналістика: робота журналіста і редактора у нових 3МІ / Перекл. 3 англ. А. Іщенка. К.: Вид. дім «Києво-Могилянська академія», 2007. 324 с.

${ }^{26}$ Захарченко $A$. Специфіка викладання практичних курсів у царині нових медіа // Наукові записки Інституту журналістики: зб. наук. праць / КНУ ім. Тараса Шевченка. Київ, 2014. Т. 5. С. 277-281. 